\title{
ABOUT ISSUE 3 OF 2021 AND THE EVOLUTION OF JUSTICE IN UKRAINE DURING THE PERIOD OF INDEPENDENCE
}

\author{
his issue of Access to Justice in Eastern Europe consists of the collection of research \\ articles focused on the evolution of justice in independent Ukraine. This year, we \\ celebrate an outstanding event - 30 years ago, Ukraine became an independent \\ state, and now, we have a great occasion to summarise some of our challenges and \\ achievements.
}

Ukraine has come a long and intricate way to the final assertion of its independence as a state. According to various estimates, the emergence and proclamation of state formations on the territory of Ukrainian lands took place seven or perhaps even nine times. ${ }^{1}$ In 1990 , during the collapse of the Soviet Union, ${ }^{2}$ Ukrainian society clearly decided its fate - in a 1991 referendum, 90.32\% confirmed the Act of Independence of Ukraine, 'continuing the millennial tradition of statehood in Ukraine. ${ }^{3}$ The recognition of Ukraine as an independent state by Poland, Canada, Hungary, the Baltic States, and other countries of the world finally marked the recognition of Ukraine's statehood on an international scale. ${ }^{4}$ Since then, the urgent task of the Ukrainian government has been to build independent state institutions, including the judiciary, on radically different principles of democracy and the rule of law.

A great deal of our present may be clarified by past events, and this helps us to understand current problems deeply and to find the most appropriate ways of solving them. Not surprisingly, this issue began with the historical study of Ivanna Matseliukh devoted to the interrelation of the Church and the Ukrainian judiciary.

Like European countries, where canon law has had a huge impact on the development of both the judicial system and the formation of basic approaches to the administration of justice, in particular, civil justice, the Orthodox Church played an important role in Ukraine. Traditionally we recognise the romano-canonic model of civil procedure and the general impact of the Church on judicial evolution in western Europe. Ukraine found itself at a crossroads between the influence of the Roman Catholic and Orthodox churches of Byzantium. In the distant tenth century, Princess Olga of Kyiv visited Constantinople and converted to their rite of Christianity, although she was later canonised by both the

1 See more about Ukrainian history in S Plokhy, The Gates of Europe: A History of Ukraine Basic Books (Reprint edition 2017); I Ševčenko, Ukraine between East and West: Essays on Cultural History to the Early Eighteenth Century (2nd edn CIUS Press 2009); R Szporluk, Russia, Ukraine, and the Breakup of the Soviet Union Hoover Institution Press (1st edn 2000); MH Taranenko, MN Taranenko, 'The First State Formations on the Territory of Ukraine' (2016) 1 Visnyk NTUU 'KPI’ Politology, Sociology, Law <https://doi.org/10.20535/2308-5053.2016.1/2(29/30).119171>

2 On the difficult times of 'perestroika' before the proclamation of Ukraine's independence in the 1990s, see T Kuzio, Ukraine: Perestroika to Independence (Macmillan Press Ltd 2000).

3 Resolution of the Verkhovna Rada of the Ukrainian SSR 'On the Declaration of Independence of Ukraine’ <https://zakon.rada.gov.ua/laws/show/1427-12\#Text> accessed 22 July 2021.

4 An interesting overview of Ukraine's identity can be found in C Shinar, Ukraine's Struggle for Independence (Cambridge University Press 2020). 
Orthodox and Catholic churches. The influence of the Church, which has operated in the form of the Kyiv Metropolitanate since 988 and, since 2019, has become an independent church, is seen as decisive in the development of the judicial system and the judiciary in Ukraine, especially in the socio-cultural and worldview aspects. In the article, you can learn more about this, as well as about the main sources of ecclesiastical law - Kormcha books, the jurisdiction of the Church, and the structure of ecclesiastical justice. The conclusions deserve support, especially the idea that the study of socio-cultural and state-church relations will provide a deeper understanding of the traditions and stereotypes of Ukrainian society that have developed over the centuries and, in turn, help us to understand the basic principles of justice, which will foster effective reform of judicial system at the present stage. Several interesting images are included in this issue to illustrate the study.

One of the most important and most difficult tasks facing the Ukrainian authorities in the 1990s was the development of the criminal justice system. Blatant and tragic human rights violations in Ukraine were pervasive, partially as a result of the use of an entire apparatus of affiliation created in the Soviet totalitarian state. Ensuring the rights and freedoms of individuals during pre-trial investigations and court proceedings in criminal cases was an urgent and significant task. The adoption of the new CrPC of independent Ukraine twenty years after the declaration of independence marked an evolutionary step towards the adoption of world standards for ensuring the rule of human rights. The article by Vasyl Shybiko, one of the leading legal scholars of Ukraine and co-author of the CrPC, analyses in detail the intricate method of reforming Ukrainian criminal procedure legislation and describes the main stages of evolution and formation of modern criminal justice in Ukraine. We sincerely hope that this work will be interesting for an international professional audience and that the Ukrainian experience will provide lessons for future generations of lawyers.

Building a system of criminal justice based on democratic legal values and ensuring the rule of law is a difficult task, especially given the traditionally established views of society, which are always contemplating the past. There is no doubt that today, it is much easier to compare the conditions of the totalitarian system of our past and selectively assess their advantages, while a comprehensive evaluation of the approaches prevailing at the time will always testify against them. In Oksana Kaluzhna's article, our readers will find an extremely interesting and thorough study devoted to the rather trivial (at first glance) issues of clothing and ranks of prosecutors - one of the most elite classes of lawyers of all time. The article contains a detailed analysis of the proposals of one of the latest draft laws submitted to the Ukrainian Parliament, as well as the requirements of almost all Council of Europe states and a comparison of their experience in ensuring the activities of prosecutors.

Another research paper in this issue is devoted to one of the most interesting and controversial issues in the functioning of the judiciary - the issue of judicial law-making, the history of its formation, and the current situation in Ukraine. Endless judicial reform, together with certain fluctuations in the approaches introduced, create the basis for distrust in the judiciary in Ukraine and its ability to provide justice. At the same time, certain steps in the creation of strong and peaceful judicial institutions have been made. The article by Taras Didych provides a detailed discussion of the legal regulation of judicial law-making, its forms and procedures, and judicial enforcement of acts and their impact. The author naturally paid special attention to the activities of the judiciary in the areas of law enforcement and lawmaking, which require strengthening the mutual interaction and influence in the current context of reforming the judicial system and the judiciary in Ukraine. Read more about this, as well as about the results of recent judicial reforms and the legislative powers of the Supreme Court and the Constitutional Court of Ukraine, in this article.

During the building of an independent state, which was supported by the vast majority of Ukrainians in the early 1990s, the level of trust in state institutions, in particular the 
judiciary, unfortunately, fell dramatically. Of course, the level of public confidence in the judiciary depends on the effectiveness of its functioning. The assessment of judicial reform in Ukraine, as well as analysis of some of its achievements and flaws, are contained in the Reforms Forum note by Maryna Stefanchuk, Oleksandr Hladun, and Ruslan Stefanchuk and will be of interest to our audience.

Another Reforms Forum note is dedicated to the reform of arbitration - one of the oldest and deservedly most effective ways of resolving disputes. One of the recent Draft Laws proposed expanding the arbitrability of disputes that could be referred to international commercial arbitration, as well as the possibility of establishing permanent arbitration institutions in Ukraine, which provoked discussion among legal practitioners and scholars. We hope that the authors' analysis of these proposals, prepared by the leading Ukrainian experts in the field of arbitration Yuriy Prytyka, Vyacheslav Komarov, and Serhiy Kravtsov, will be of interest to our readership.

Several interesting and informative notes have also been included in this issue due to their importance for further research, among which is the study of limits of a judge's freedom of his/her opinion expression in the context of Ukrainian and ECtHR case-law by Oksana Khotynska-Nor and Lidiia Moskvych. The particular note should attract attention due to its connection to legislative reform and creating relevant case-law.

Finally, let me share some of our latest accomplishments. Last month, AJEE was finally fully indexed in Scopus, Elsevier, and, on this occasion, I want to thank all our team my excellent managing editors, respectful Editorial Board members, attentive reviewers and language editors, and authors, who helped us to share the results of research in the area of judiciary and civil justice, as well as criminal procedure among the wide audience of professional scholars and practitioners. I sincerely hope that legal science will blossom and bring the fruit of peace and strong institutions, the rule of law, and equal access to justice to our world.

Editor-in-Chief

\section{Prof. Iryna Izarova}

Law School, Taras Shevchenko National University of Kyiv, Ukraine 